\title{
AN EMPIRICAL INVESTIGATION OF JOB AND FAMILY STRESSORS AMONGST FIREFIGHTERS IN THE SOUTH AFRICAN CONTEXT
}

\author{
R M OOSTHUIZEN \\ P KOORTZEN \\ oosthrm@unisa.ac.za \\ Department of Industrial and Organisational Psychology \\ University of South Africa
}

\begin{abstract}
The general aim of the research was to theoretically and empirically study and evaluate job and family stressors amongst firefighters in the South African context. This also included an empirical evaluation of the stress symptoms of firefighters. The research was quantitative, consisting of a survey design. Three measuring instruments were used, namely the Experience of Work and Life Circumstances questionnaire, the Stress questionnaire as well as a biographical questionnaire. Task characteristics, organisational functioning, physical working conditions and job equipment, career and social matters, remuneration, fringe benefits and personnel policy were identified as causes of job stress originating within the work situation. Marital dysfunction and divorce, limited time with the family, problems with children, alcohol and drug abuse, lack of exercise, suicide, anger aimed at family members, physical and emotional exhaustion, lonely marital partners, unavailability to help the family when needed and depression were identified as causes of family stress arising outside the work situation.
\end{abstract}

Key words

Job stress, family stress, firefighters, task characteristics, organisational functioning, physical conditions and

equipment, career and social matters, remuneration

Firefighters providing emergency services to the public are involved with some of the most tragic aspects of the boundary between life and death, often in a context over which they have little or no control. A number of authors have noted that such situations may produce untoward stress responses in firefighters which may play a negative role in their performance, or even cause them to prematurely resign (Graham, 1981; Mitchell, 1983; Willis, 1993). Stress also contributes to psychological symptoms, for example cognitive, affective and behaviour symptoms (Hartsough, 1985; Mitchell \& Bray, 1990). Cox (1978; 2000) indicated that the characteristics of excessive tension are a lack of concentration and limited memory. These contribute to a decrease in productivity, which may increase the level of stress experienced. A person's perception of him/herself may be negatively influenced by stress caused by the feeling that his/her contribution at work, at home, and in the community is not significant. This research focuses on job and family stressors amongst firefighters.
A model of job stressors of firefighters was compiled after an extensive literature study (Koortzen, 1996; Shakespeare-Finch, Smith \& Obst, 2002; Waters, 2002). The job stressors of firefighters can be categorised in two distinguishable areas namely stressors arising outside the work situation and stressors originating within the work situation as depicted in Figure 1.

The causes of the stressors arising outside the work situation were characterised by marital dysfunction and divorce, limited time with family, problems with children, and lifestyle factors such as the abuse of alcohol, excessive smoking and lack of exercise (Roberts \& Levenson, 2001). Further issues include the long shifts, which interfere with their sex lives, loss of friends (non firefighters), suicide of colleagues or family members, lower social status, anger and frustration at home or in the family, emotional, intellectual and physical exhaustion, wives being alone at night and not being available to help the family when needed (He, Zhao $\&$ Archbold, 2002; Shakespeare-Finch et al., 2002).

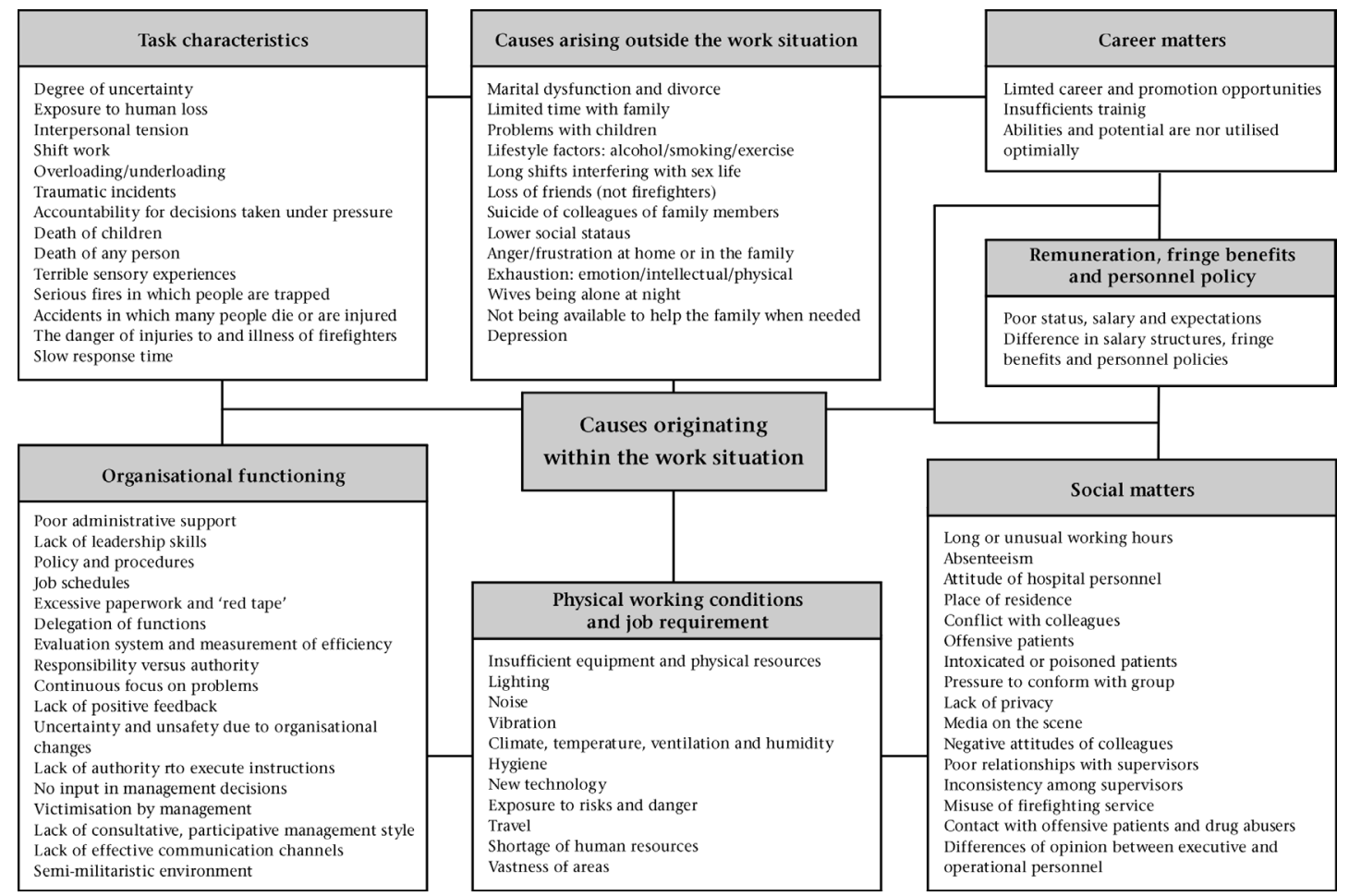

Figure 1: Model of job stressors of firefighters (Kootzen, 1996; Shakespeare-Finch et al., 2002; Waters, 2002) 
The causes of the stressors originating within the work situation manifested in terms of tasks characteristics, organisational functioning, physical working conditions and job equipment, career and social matters, remuneration, fringe benefits and personnel policy (Waters, 2002). The degree of uncertainty, exposure to human loss, interpersonal tension, shift work, overloading, underloading and traumatic incidents were flagged as main task characteristics stressors (Lemanski \& Samuels, 2003; Regehr, Johanis, Dimitropoulos, Bartram \& Hope, 2003).

Administrative stressors include poor administrative support, lack of leadership skills, policy and procedures, job schedules, excessive paperwork and red tape, delegation of functions, evaluation system and measurement of effectivity, responsibility versus authority, continuous focus on problems, and a lack of positive feedback. Job stressors in terms of organisational functioning were further characterised by uncertainty and unsafety (Peltzer, 2001; Wiese, Rothmann \& Storm, 2003).

Insufficient equipment and resources, physical working conditions, lightning, noise, vibration, climate, temperature, ventilation, humidity, hygiene, new technology, exposure to risks and dangers, travel, shortage of human resources and vastness of areas were also identified as major job stressors. Career job stressors were characterised by limited career and promotion opportunities, insufficient training, and failure to optimally utilise the abilities and potential of firefighters. Long or unusual working hours, absenteeism, attitude of hospital personnel, the place of residence, conflict with colleagues, offensive and intoxicated or poisoned patients, media on the scene, pressure to conform with the group, and lack of privacy were the main social job stressors for firefighters. The lack of social status, low salaries and low expectations were also very significant job stressors. Apart from the intrapsychological impact of stress, it also impacts on interpersonal relationships (Perry, 1999; Torres, Maggard \& Torres, 2003).

\section{Family stress amongst firefighters}

Family stress is defined as pressure or tension in the family system. It is a disturbance in the steady state of the family. This is normal and even desirable at times. Stress is inevitable, because people (and therefore families) develop and change over time. With change comes disturbance, pressure - what one calls stress. Family routines change, patterns of interaction change, people are born and people die (Boss, 1988). Family stress occurs when feedback indicates that the system does not have the requisite variety of rules to comfortably transform inputs into outputs that meet desirable standards (Shakespeare-Finch et al., 2002). In other words, the process of stress occurs when the usual transformation processes are not sufficient for families to handle a change or new input in the system. Rather than engaging in their usual and preferred activities, families find themselves asking "What are we going to do?" and "How are we going to deal with this situation?" (Burr \& Klein, 1994). The outcome of this may be that stress at work and at home are without doubt the reason that highly qualified and loyal firefighters give themselves over to alcohol -or drug abuse, extramarital relationships and suicide thoughts, which play a role in family disintegration, depression, aggression and frustration (Fullerton, Ursano \& Wang, 2004). Apart from stressors this research also focuses on the stress reactions and symptoms amongst firefighters.

\section{Stress reactions and symptoms amongst firefighters}

The symptoms of job stress amongst firefighters can be summarised in the following areas, namely somatic symptoms, obsessive-compulsive behaviour, interpersonal sensitivity, depression and anxiety. The symptoms can be viewed as symptoms that might manifest in a wide spectrum of the firefighting population in similar or different circumstances. Somatic symptoms refers to physical symptoms suggestive of physical disorders, but no organic abnormalities can be found to account for them. Moreover, there is evidence, or some reason to believe, that the symptoms reflect psychological factors or conflict (Linienfeld, 1998; Smith, Manning \& Petruzzello, 2001).

Obsessive-compulsive behaviour refers to an obsession which is an intrusive and recurrent thought, idea, or urge that seems beyond the person's ability to control. Obsessions can be potent and persistent enough to interfere with daily life and can engender significant distress and anxiety (Davison, Neale \& Kring, 2004). A compulsion is a repetitive behaviour or mental act that the person feels compelled or driven to perform. Interpersonal sensitivity can be described as a characteristic pattern of a person to perceive, or to perceive or interpret, the relationship between the person and other persons (Dozois \& Backs-Dermott, 2000).

Depression refers to a breakdown of psychological defences, leading into the downward mental and emotional spiral of despair, ultimately resulting in the emotional state of depression, from which the road to recover is often painful and difficult. Anxiety is a generalised state of apprehension or foreboding, an emotional state characterised by physiological arousal and unpleasant feelings of tension (Monnier, Cameron, Hobfoll \& Gribble, 2002). Considering the descriptions of the afore-mentioned symptoms and psychological reactions such as identification with the victims and the dead, helplessness and guilt, fear of the unknown and physical reaction on the alarm, it becomes apparent that anxiety forms a part of almost all of these symptoms and reactions. The empirical measurement of the symptoms by means of the Stress questionnaire will provide a better understanding of the causes of stress and how it precipitate in intra-psychical and interpersonal outcomes (Fishkin, 1992).

The literature survey produced very little results on the job and family stress of firefighters in the South African context. The problem exists that quantitative measurements of these constructs as well as the nature of the resulting symptoms are not available for South African firefighters. The specific research problems that these researchers wanted to address included the following:

Firstly, to determine to what extent biographical characteristics influence the work and life stress of firefighters. It is therefore hypothesised that significant correlations exist between biographical characteristics and work and life stress levels. Secondly, the researchers wanted to establish which of the causes of stress (as represented by the scores on the subscales of the Experience of Work and Life Circumstances Questionnaire) play a more prominent role in the two broad dimensions of causes arising outside the work situation (COW) and causes originating within the work situation (CIW). In this regard it was hypothesised that significant correlations exist between the subscales of the Experience of Work and Life Circumstances Questionnaire and the two broad dimensions (COW and CIW). Finally, the researchers wanted to explore the stress reactions and symptoms further. Although some degree of anxiety and even depression at times can be expected, the researchers wanted to explore the manifestations of these stress reactions. For example: How would depression manifest in the relationships of firefighters? It was therefore hypothesised that there are significant correlations between the subscales of the Stress Questionnaire (inter alia: somatication, obsessive-compulsive, interpersonal sensitivity, depression and anxiety).

\section{The aim of the research}

The general aim of the research was to theoretically and empirically study and evaluate job and family stressors, as well as the stress symptoms of firefighters in the South African context. 


\section{RESEARCH DESIGN}

\section{Research approach}

The research was quantitative of nature with a survey design. The process of data collection commenced by obtaining approval for the research from the council of the Metropolitan Municipality. The consent of the respondents was obtained via their District Commanders. The respondents were welcomed and put at ease with the commencement of the administration of the questionnaires. They were asked to answer the questions truthfully and accurately. Respondents were given verbal instructions regarding the completion of the questionnaires and were assured of the confidentiality of the research. It was explained to the respondents that different questionnaires will be administered to measure the effect of stress, and that the completion of the questionnaires will depend on their individual completion rate. Data was collected over a period of a week, on different occasions. The results were discussed with the respondents where such a need was expressed.

\section{Participants}

The sample consisted of 241 available firefighters of the Metropolitan Municipality. The sample consisted of single, married and divorced males and females from different population, language and age groups. The following ranks of firefighters were distinguished namely, Learner firefighter Gr 1 11, Junior firefighter, Senior firefighter; Leading firefighter, Station Officer and Divisional Officer. The firefighters were recruited from the different fire brigades to participate in the empirical investigation after a motivational speech was delivered at a meeting of the District Commanders.

\section{Measuring instruments}

A Biographical questionnaire was compiled to obtain the following information: Age, gender, dependants (number), marital status, home language, post (level), years experience in service, academic qualification, number of subordinates and the nature of shift work. The Biographical questionnaire provided a general profile of the firefighters in terms of the dimensions mentioned above. Information was also obtained in terms of the frequency of attending to emergency calls and experience of the job as stressful. The first hypothesis can be formulated that there are certain significant correlations between the biographical characteristics (inter alia: age, gender, marital status, job experience, academic qualification) and the extent to which work and life stress is experienced (inter alia: causes arising outside the work situation, organisational functioning, task characteristics, physical working conditions and job equipment, career and social matters, and remuneration, fringe benefits and personnel policy).

The Experience of Work and Life Circumstances Questionnaire (Van Zyl \& Van der Walt, 1991) is based on the experience and causes of job stress. The rationale of the questionnaire is that a person with a high score on the items indicates a high level of stress experience, which relates to problems from the environment. The questionnaire can be utilised for the measurement of the stress levels experienced as well as the nature of the important causes of stress of employees that are at a grade 10 level. The results can be utilised to identify employees that are functioning under high levels of stress and to determine the main stressors in their environments. This self-assessment questionnaire consists of two dimensions, namely: experience of the job and circumstances and expectations of the job. The first dimension of the questionnaire, which measures the way the job is experienced, indicates the level of stress of the employee, and whether an employee experiences stress at a normal, high or very high level. Measurement is conducted through the assessment of 40 questions on a five-point scale (Scale A), which indicate how often certain stress emotions (for example depression, anxiety and frustration) occur. A high score indicates a high level of stress.
The second dimension of the questionnaire measures the circumstances and expectations of the job and indicates the level of stress experienced by the employee. Questions are answered on a five-point scale (Scale B in the case of circumstances and Scale C in the case of expectations) to indicate how often specific emotions occur. There is a total of 76 questions pertaining to persons circumstances and unfulfilled expectations. The levels and causes of stress can be measured by administering the questionnaire (Van Zyl \& Van der Walt, 1991). The second hypothesis can be formulated that there are certain correlations between the subscales of the Experience of work and life circumstances questionnaire (inter alia: causes arising outside the work situation, organisational functioning, task characteristics, physical working conditions and job equipment, career and social matters, and remuneration, fringe benefits and personnel policy).

The construct validity of the questionnaire was investigated using appropriate factors of the 16PF-questionnaire (Forms A and E), the PHSF-Relationships-questionnaire and the cognitive and behavioural symptoms. The construct validity of the questionnaire is further supported with the moderate relationship with the different fields of the Experience of work and life circumstances questionnaire. Reliability coefficients, as measured by the Kuder-Richardson Formula 8 range from 0,83 to 0,92 , and test-retesting, which vary from 0,62 to 0,80 correlates favourably with reliability coefficients which is reported for similar questionnaires (Van Zyl \& Van der Walt, 1991).

The rationale of the Stress Questionnaire (Gmelch, 1982) is that since it measures the occurrence of a particular stress experience of an individual, it can be utilised to measure high intensities of stress symptoms. The aim of the questionnaire is to determine whether individuals, who are regularly subjected to crisis situations, will display symptoms of stress or not, and to determine the intensity of the stress symptoms they experience. The questionnaire consists of five dimensions, namely somatic, obsessive-compulsive behaviour, interpersonal sensitivity, depression, and anxiety and also provides a total score for stress.

The questionnaire can be administered in an individual and/or a group context. The questionnaire consist of 45 items, which focus on the measurement of the occurrence of a particular stress experience (Derogatis et al., 1974). The respondent is requested to complete each item on a "how often" basis. The occurrence is measured through the selection by the respondent of one of the following alternatives: $1=$ never; $2=$ seldom; $3=$ often and $4=$ almost always. There is no time limit for the completion of the questionnaire. The questionnaire is scored and interpreted in terms of the separate scores for each of the five dimensions (Gmelch, 1982). With regard to content, the questionnaire seems to be suitable for determining whether individuals who are regularly subjected to crisis situations, will display symptoms of stress or not, and to determine the intensity of the stress symptoms experienced (Derogatis et al., 1974).

Literature does not provide any reliability and validity indexes for the questionnaire. The motivation for the inclusion of the questionnaire in the research is that more comprehensive information will be obtained with this questionnaire in conjunction with the other instruments used to measure the experience of stress of firefighters. A third hypothesis can be formulated that there are certain correlations between the subscales of the Stress questionnaire (inter alia: somatication, obsessive-compulsive behaviour, interpersonal sensitivity, depression and anxiety).

\section{Procedure}

The questionnaires were administered in 12 sessions. The firefighters of the Northern and Southern regions were divided into three shifts. The respondents participating in each shift in the various regions were welcomed at the sessions and set at ease with the commencement of the administration of the questionnaires. 


\section{Statistical Analysis}

The statistical analysis involved that the two questionnaires were marked separately and the scores obtained by the firefighters were calculated. The percentiles (P5 and P95) were computed to determine the $10 \%$ of the firefighters that obtained a low stress score and the $10 \%$ of the firefighters that obtained a high stress score. The most suitable five firefighters from each of these groups were selected to obtain the best possible rapport during the interviewing. The SAS computer program for the Social Sciences (1999) was used for the statistical calculations.

The means were used to describe the results. The mean is the sum of all the scores in the distribution divided by the number of scores in the distribution. This mean was used to compute the average scores that were obtained for the different components of the questionnaires (Bless \& Higson-Smith, 2000). The standard deviation and the minimum and maximum values were used to describe the results. The standard deviation is the (positive) squared root of the variance. The value of the standard deviation indicates how much the scores vary. The larger the value of the standard deviation, the more the scores varies. The more the scores vary, the more heterogeneous the sample of firefighters will be. If the value of the standard deviation is small, the sample of firefighters is more homogeneous (Bless \& Higson-Smith, 2000). Scatter correlations as well as linear correlations were computed. The Pearson product-moment correlation (Pearson's $r$ ) indicates the linear correlation between two variables. It is a value between -1 and +1 . A calculated $r$ of 0.86 indicates a strong positive relationship, whereas a calculated $r$ of -0.12 indicates a weak negative relationship (Bless \& Higson-Smith, 2000).

\section{RESULTS}

The data was analysed and the descriptive statistics are presented with frequencies, mean scores and standard deviations. Confirming research has been conducted to link the working conditions in a specific position to the physical and mental well-being of the incumbent. Research findings have indicated that poor mental health can be linked to unpleasant working conditions, which include having to work very fast, the rendering of many physical outputs, and extreme working hours (Pike, 2003). The mean scores of the Experience of Work and Life Circumstances Questionnaire are presented in Table 1.

\section{TABLE 1}

MEAN SCORES OF THE EXPERIENCE OF WORK AND LIFE CIRCUMSTANCES QUESTIONNAIRE

\begin{tabular}{lcccccc}
\hline Variable & N & Mean & $\begin{array}{c}\text { Standard } \\
\text { deviation }\end{array}$ & Sum & Minimum & Maximum \\
\hline Level & 232 & 83,09914 & 21,36396 & 19279 & 42,00000 & 158,00000 \\
COW & 232 & 53,42672 & 12,18486 & 12395 & 26,00000 & 86,00000 \\
Field 1 & 232 & 16,97414 & 6,67873 & 3938 & 2,00000 & 34 \\
Field 2 & 232 & 44,93966 & 8,36897 & 10426 & 14,00000 & 66 \\
Field 3 & 232 & 18,13793 & 7,05746 & 4208 & 3,00000 & 34,00000 \\
Field 4 & 232 & 22,43966 & 6,64080 & 5206 & 6,00000 & 38 \\
Field 5 & 232 & 23,02155 & 5,90285 & 5341 & 6,00000 & 34 \\
Field 6 & 232 & 24,65948 & 7,98269 & 5721 & 3,00000 & 50 \\
CIW & 232 & 150,17241 & 32,819 & 34840 & 51 & 245 \\
Stress total 1 & 232 & 286,69828 & 34,77378 & 66514 & 127,00000 & 400 \\
\hline
\end{tabular}

Note

Level $=$ Stress leve

COW $=$ Causes arising outside the work situation

Field $1=$ Organisational functioning

Field $1=$ Organisational function
Field $2=$ Task characteristics

Field $3=$ Physical working conditions and job equipment

Field $4=$ Career matters

Field $5=$ Social matters

Field $6=$ Remuneration, fringe benefits and personnel policy

$\mathrm{CIW}=$ Causes originating within the work situation

Stresstotal 1 = Stress total for the Experience of work and life circumstances questionnaire
The mean score of 53,42 of the variable COW (causes arising outside the work situation) indicates that the firefighters experienced family stress. A standard deviation of 12.18 was obtained. Similar literature findings were experienced in terms of marital dysfunction and divorce, limited time with family, problems with children, and lifestyle factors such as the abuse of alcohol, excessive smoking and lack of exercise (Roberts \& Levenson, 2001). Further issues include the long shifts, which interfere with their sex lives, loss of friends (not firefighters), suicide of colleagues or family members, lower social status, anger and frustration at home or in the family, emotional, intellectual and physical exhaustion, wives being alone at night and not being available to help the family when needed (He, Zhao \& Archbold, 2002; Shakespeare-Finch et al, 2002).

The mean score of 44,93 and the standard deviation of 8,36 of the Field 2 variable indicate that firefighters experienced task characteristics as the main cause of stress originating within the work situation. The mean scores for the Field 1 and Field 3 variables were 16,97 and 18,13 respectively and the corresponding standard deviations were 6,67 and 7,05. It can be concluded that organisational functioning and physical working conditions and job equipment caused the least stress for firefighters within the work situation. The mean scores of 22,43, 23,02 and 24,65 for the Field 4, Field 5 and Field 6 variables indicate that firefighters experience career and social matters as well as remuneration, fringe benefits and personnel policy as moderate causes of stress originating within the work situation. Standard deviations of $6,64,5,90$ and 7,98 were obtained. Confirming literature findings were experienced. Task characteristics that cause stress are accountability for decisions taken under pressure, death of people, terrible sensory experiences, serious fires in which people are trapped, accidents in which many people are injured, the danger of injuries to and illness of firefighters, and slow response time. Firefighters witness how people are injured because of accidents or physical violence, or even die as a result thereof. The perception amongst firefighters might exist that they and other people are very vulnerable (Waters, 2002).

The stress symptoms and reactions of firefighters were analysed next. Table 2 illustrates the mean scores of the variables of the Stress questionnaire.

TABLE 2

MEAN SCORES OF THE VARIABLES OF THE STRESS QUESTIONNAIRE

\begin{tabular}{lcccccc}
\hline Variable & N & Mean & $\begin{array}{c}\text { Standard } \\
\text { deviation }\end{array}$ & Sum & Minimum & Maximum \\
\hline Mean SQ 1 & 232 & 1,74916 & 0,54844 & 405,80534 & 1 & 3,5 \\
Mean SQ 2 & 232 & 2,00659 & 0,5398 & 465,52976 & 1 & 3,375 \\
Mean SQ 3 & 232 & 1,95072 & 0,54684 & 452,56667 & 1 & 3,71429 \\
Mean SQ 4 & 232 & 1,82786 & 0,53285 & 424,06277 & 1 & 4 \\
Mean SQ 5 & 232 & 1,88397 & 0,52229 & 437,08095 & 1 & 3,33333 \\
Stress total 2 & 232 & 296,11658 & 35,49318 & 68699 & 132,09091 & 415,40747
\end{tabular}

Note

Mean SQ 1 = Mean of somatic component of Stress questionnaire

Mean SQ 2 = Mean of obsessive-compulsive component of Stress questionnaire

Mean SQ $3=$ Mean of interpersonal sensitivity component of Stress questionnaire

Mean SQ 4 = Mean of depression component of Stress questionnaire

Mean SQ $5=$ Mean of anxiety component of Stress questionnaire

Mean SQ $5=$ Mean of anxiety component of Stress questic
Stress total $2=$ Stress total for the Stress questionnaire

Table 2 indicates that the highest mean score of 2,00 was obtained for the variable SQ2, with a standard deviation of 0,53 . The lowest mean score of 1,74 was obtained for the variable SQ 1 , with a standard deviation of 0,54 . The behaviour of the firefighters was depicted as mostly obsessive-compulsive and, to a lesser extent somatic. The mean scores of $1,95,1,82$ and 1,88 were obtained for the variables SQ3, SQ4 and SQ5, and the 
standard deviations were 0,54, 0,53 and 0,52 respectively. Interpersonal sensitivity, depression and anxiety were experienced by the firefighters at almost equal levels. Similar literature findings were experienced. For example, firefighters may think that their bodies remain dirty after working with protective clothing despite repeated washing. Furthermore, firefighters may recheck that they did check the firefighting equipment (Garcia, 2003; Phebe, Pfefferbaum, Nixon \& Dickson, 2000; Young, 2001).

A further analysis of the results was done by inferential statistics which confirmed the first hypothesis that there were certain significant correlations between the biographical characteristics (inter alia: age, gender, marital status, job experience, academic qualification) and the extent to which work and life stress is experienced (inter alia: causes arising outside the work situation, organisational functioning, task characteristics, physical working conditions and job equipment, career and social matters, and remuneration, fringe benefits and personnel policy). The results that are presented in Table 3 are the correlation between the levels of stress that the firefighters experience in their job, and their age.

TABLE 3

STRESS LEVEL: AGE

\begin{tabular}{lcccc}
\hline Age & N & Mean & Standard deviation & Pr > F \\
\hline $18-25$ & 32 & 81,1875 & 19,929614 & 0,06 \\
$26-30$ & 56 & 86,2321429 & 24,3228221 & \\
$31-40$ & 119 & 83,1932773 & 21,0561305 & \\
$41-54$ & 27 & 73,037037 & 12,5467786 & \\
\hline
\end{tabular}

A mean score of 86,23 indicates that the firefighters in the age category of 26 - 30 years experience more job stress than those in the other age categories. A standard deviation of 24,32 was obtained. A P-value of 0,0598 indicates a significant relation between the level of job stress experienced and age of firefighters. The results presented in Table 4 relate to the correlation between the levels of job stress experienced by firefighters, and their marital status.

TABLE 4

STRESS LEVEL: MARITAL STATUS

\begin{tabular}{lcccc}
\hline Marital status & N & Mean & Standard deviation & Pr > F \\
\hline Married & 152 & 84,9802632 & 21,7601222 & 0,03 \\
Unmarried & 63 & 78,5555556 & 18,9692262 & \\
Divorced & 20 & 74,65 & 20,4071066 & \\
\hline
\end{tabular}

A mean score of 84,98 indicates that the stress levels of married firefighters are higher than those in the other categories. A standard deviation of 21,76 was obtained. A P-value of 0,0293 indicates a significant relation between job stress and the marital status of firefighters. The results that are presented in Table 5 are the correlation between the causes arising outside the work situation and the marital status of the firefighters.

TABLE 5

CAUSES ARISING OUTSIDE THE WORK SITUATION: MARital Status

\begin{tabular}{lcccc}
\hline Marital status & N & Mean & Standard deviation & Pr > F \\
\hline Married & 152 & 54,7302632 & 12,3449163 & 0 \\
Unmarried & 63 & 50,3650794 & 11,3483004 & \\
Divorced & 20 & 46,8 & 12,2971969 & \\
\hline
\end{tabular}

A mean score of 54,73 indicates that the married firefighters experience more family stress due to causes arising outside the work situation than the firefighters in other categories. A standard deviation of 12,34 was obtained. A P-value of 0,0039 indicates a significant relation between family stress and the marital status of firefighters. The results that are presented in Table 6 are the correlation between the stress total for all the variables of the Experience of work and life circumstances questionnaire and the marital status of the firefighters.

TABLE 6

STRESS TOTAL: MARital STATUS

\begin{tabular}{lcccc}
\hline Marital status & N & Mean & Standard deviation & Pr > F \\
\hline Married & 149 & 289,516779 & 34,1165736 & 0,03 \\
Unmarried & 59 & 287,288136 & 32,044716 & \\
Divorced & 20 & 267,25 & 45,0483658 & \\
\hline
\end{tabular}

A mean score of 289,51 indicates that the married firefighters experience more job stress than those in the other categories. A standard deviation of 34,11 was obtained. A P-value of 0,0278 indicates a significant relation between job stress and the marital status of firefighters. The results that are presented in Table 7 are the correlation between the causes originating within the work situation and the years' experience in the firefighting occupation.

TABLE 7

CAUSES ORIGINATING WITHIN THE WORK SITUATION: YEARS' EXPERIENCE IN OCCUPATION

\begin{tabular}{lcccc}
\hline $\begin{array}{l}\text { Years experience } \\
\text { in occupation }\end{array}$ & N & Mean & $\begin{array}{l}\text { Standard } \\
\text { deviation }\end{array}$ & Pr > F \\
\hline Less than 2 years & 26 & 164,884615 & 33,8329152 & 0,04 \\
2 - 5 years & 33 & 155,242424 & 30,642118 & \\
6 - 10 years & 36 & 144,916667 & 36,7807209 & \\
More than 10 years & 129 & 146,96124 & 31,4859599 & \\
\hline
\end{tabular}

The above information indicates that the firefighters with less than 2 years experience in their occupation (mean score of 164,88 ) experience more job stress due to causes originating within the work situation than the firefighters in the other categories. A standard deviation of 33,83 was obtained. A P-value of 0,0427 indicates a significant relation between the causes originating within the work situation and the years' experience in the firefighting occupation.

A further in-depth analysis of the results by means of correlation statistics indicated specific prominent stressors. The second hypothesis that there are certain correlations between the subscales of the Experience of work and life circumstances questionnaire (inter alia: causes arising outside the work situation, organisational functioning, task characteristics, physical working conditions and job equipment, career and social matters, and remuneration, fringe benefits and personnel policy) was confirmed. Correlation statistics in Table 8 provides the following significant Pearson Correlation Coefficients of the Experience of work and life circumstances questionnaire. 
TABLE 8

PeARson CORRelation COEFFICIENTS OF THE EXPERIENCE OF WORK AND LIFE CIRCUMSTANCES QUESTIONNAIRE

\begin{tabular}{|c|c|c|c|c|c|c|c|c|c|c|}
\hline & Level & cow & Field 1 & Field 2 & Field 3 & Field 4 & Field 5 & Field 6 & CIW & $\begin{array}{r}\text { Stress } \\
\text { total } 1\end{array}$ \\
\hline Level & 1,00000 & $\begin{array}{r}0,67321 \\
<, 0001\end{array}$ & $\begin{array}{r}-0,32720 \\
<, 0001\end{array}$ & $\begin{array}{r}-0,16350 \\
0,0126\end{array}$ & $\begin{array}{r}-0,29275 \\
<, 0001\end{array}$ & $\begin{array}{r}-0,28344 \\
<, 0001\end{array}$ & $\begin{array}{r}-0,43564 \\
<, 0001\end{array}$ & $\begin{array}{r}-0,23219 \\
0,0004\end{array}$ & $\begin{array}{r}-0,36341 \\
<, 0001\end{array}$ & $\begin{array}{r}0,50728 \\
<, 0001\end{array}$ \\
\hline COW & $\begin{array}{r}0,67321 \\
<, 0001\end{array}$ & 1,00000 & $\begin{array}{r}-0,37276 \\
<, 0001\end{array}$ & $\begin{array}{r}-0,14039 \\
0,0326\end{array}$ & $\begin{array}{r}-0,35393 \\
<, 0001\end{array}$ & $\begin{array}{r}-0,28769 \\
<, 0001\end{array}$ & $\begin{array}{r}-0,40140 \\
<, 0001\end{array}$ & $\begin{array}{r}-0,30417 \\
<, 0001\end{array}$ & $\begin{array}{r}-0,39216 \\
<, 0001\end{array}$ & $\begin{array}{r}0,39389 \\
<, 0001\end{array}$ \\
\hline Field 1 & $\begin{array}{r}-0,32720 \\
<, 0001\end{array}$ & $\begin{array}{r}-0,37276 \\
<, 0001\end{array}$ & 1,00000 & $\begin{array}{r}0,41503 \\
<, 0001\end{array}$ & $\begin{array}{r}0,63673 \\
<, 0001\end{array}$ & $\begin{array}{r}0,74186 \\
<, 0001\end{array}$ & $\begin{array}{r}0,62416 \\
<, 0001\end{array}$ & $\begin{array}{r}0,66809 \\
<, 0001\end{array}$ & $\begin{array}{r}0,87114 \\
<, 0001\end{array}$ & $\begin{array}{r}0,49053 \\
<, 0001\end{array}$ \\
\hline Field 2 & $\begin{array}{r}-0,16350 \\
0,0126\end{array}$ & $\begin{array}{r}-0,14039 \\
0,0326\end{array}$ & $\begin{array}{r}0,41503 \\
<, 0001\end{array}$ & 1,00000 & $\begin{array}{r}0,34440 \\
<, 0001\end{array}$ & $\begin{array}{r}0,49362 \\
<, 0001\end{array}$ & $\begin{array}{r}0,55508 \\
<, 0001\end{array}$ & $\begin{array}{r}0,25940 \\
<, 0001\end{array}$ & $\begin{array}{r}0,67634 \\
<, 0001\end{array}$ & $\begin{array}{r}0,48868 \\
<, 0001\end{array}$ \\
\hline Field 3 & $\begin{array}{r}-0,29275 \\
<, 0001\end{array}$ & $\begin{array}{r}-0,35393 \\
<, 0001\end{array}$ & $\begin{array}{r}0,63673 \\
<, 0001\end{array}$ & $\begin{array}{r}0,34440 \\
<, 0001\end{array}$ & 1,00000 & $\begin{array}{r}0,49508 \\
<, 0001\end{array}$ & $\begin{array}{r}0,43211 \\
<, 0001\end{array}$ & $\begin{array}{r}0,55025 \\
<, 0001\end{array}$ & $\begin{array}{r}0,74418 \\
<, 0001\end{array}$ & $\begin{array}{r}0,39847 \\
<, 0001\end{array}$ \\
\hline Field 4 & $\begin{array}{r}-0,28344 \\
<, 0001\end{array}$ & $\begin{array}{r}-0,28769 \\
<, 0001\end{array}$ & $\begin{array}{r}0,74186 \\
<, 0001\end{array}$ & $\begin{array}{r}0,49362 \\
<, 0001\end{array}$ & $\begin{array}{r}0,49508 \\
<, 0001\end{array}$ & 1,00000 & $\begin{array}{r}0,57070 \\
<, 0001\end{array}$ & $\begin{array}{r}0,61432 \\
<, 0001\end{array}$ & $\begin{array}{r}0,83773 \\
<, 0001\end{array}$ & $\begin{array}{r}0,51569 \\
<, 0001\end{array}$ \\
\hline Field 5 & $\begin{array}{r}-0,43564 \\
<, 0001\end{array}$ & $\begin{array}{r}-0,40140 \\
<, 0001\end{array}$ & $\begin{array}{r}0,62416 \\
<, 0001\end{array}$ & $\begin{array}{r}0,55508 \\
<, 0001\end{array}$ & $\begin{array}{r}0,43211 \\
<, 0001\end{array}$ & $\begin{array}{r}0,57070 \\
<, 0001\end{array}$ & 1,00000 & $\begin{array}{r}0,40273 \\
<, 0001\end{array}$ & $\begin{array}{r}0,75479 \\
<, 0001\end{array}$ & $\begin{array}{r}0,30406 \\
<, 0001\end{array}$ \\
\hline Field 6 & $\begin{array}{r}-0,23219 \\
0,0004\end{array}$ & $\begin{array}{r}-0,30417 \\
<, 0001\end{array}$ & $\begin{array}{r}0,66809 \\
<, 0001\end{array}$ & $\begin{array}{r}0,25940 \\
<, 0001\end{array}$ & $\begin{array}{r}0,55025 \\
<, 0001\end{array}$ & $\begin{array}{r}0,61432 \\
<, 0001\end{array}$ & $\begin{array}{r}0,40273 \\
<, 0001\end{array}$ & 1,00000 & $\begin{array}{r}0,76041 \\
<, 0001\end{array}$ & $\begin{array}{r}0,46843 \\
<, 0001\end{array}$ \\
\hline CIW & $\begin{array}{r}-0,36341 \\
<, 0001\end{array}$ & $\begin{array}{r}-0,39216 \\
<, 0001\end{array}$ & $\begin{array}{r}0,87114 \\
<, 0001\end{array}$ & $\begin{array}{r}0,67634 \\
<, 0001\end{array}$ & $\begin{array}{r}0,74418 \\
<, 0001\end{array}$ & $\begin{array}{r}0,83773 \\
<, 0001\end{array}$ & $\begin{array}{r}0,75479 \\
<, 0001\end{array}$ & $\begin{array}{r}0,76041 \\
<, 0001\end{array}$ & 1,00000 & $\begin{array}{r}0,58310 \\
<, 0001\end{array}$ \\
\hline Stress total 1 & $\begin{array}{r}0,50728 \\
<, 0001\end{array}$ & $\begin{array}{r}0,39389 \\
<, 0001\end{array}$ & $\begin{array}{r}0,49053 \\
<, 0001\end{array}$ & $\begin{array}{r}0,48868 \\
<, 0001\end{array}$ & $\begin{array}{r}0,39847 \\
<, 0001\end{array}$ & $\begin{array}{r}0,51569 \\
<, 0001\end{array}$ & $\begin{array}{r}0,30406 \\
<, 0001\end{array}$ & $\begin{array}{r}0,46843 \\
<, 0001\end{array}$ & $\begin{array}{r}0,58310 \\
<, 0001\end{array}$ & 1,00000 \\
\hline
\end{tabular}

Note

Level $=$ Stress level

COW $=$ Causes arising outside the work situation

Field $1=$ Organisational functioning

Field 2 = Task characteristics

Field $3=$ Physical working conditions and job equip ment

Field $4=$ Career matters

Field $5=$ Social matters

Field $6=$ Remuneration, fringe benefits and personnel policy

$\mathrm{CIW}=$ Causes originating within the work situation

Stresstotal 1 = Stress total for the Experience of work and life circumstances questionnaire

A number of significant results concerning job and family stressors were found.

The results (P-value of 0.87114 ) indicate that there is a positive correlation between the causes of stress originating within the work situation and organisational functioning, which implies that the latter contributes to the job stress experienced by firefighters. Confirming literature findings were found. Organisational stressors include poor administrative support, lack of leadership skills, policy and procedures, job schedules, excessive paperwork and red tape, delegation of functions, evaluation system and measurement of effectivity, responsibility versus authority, continues focus on problems, and a lack of positive feedback (Beaton, Johnson, Infield, Ollis \& Bond, 2001).

The results (P-value of 0,74418 ) indicate that there is a positive correlation between the causes of stress originating within the work situation and physical working conditions and equipment, which implies that the latter contributes to the job stress experienced by firefighters. Similar literature findings were found. Having to work with insufficient equipment due to the economic climate in South Africa, may also cause job stress. Firefighters at a certain fire station on the East Rand indicated that they were afraid to respond to an emergency call using some of their ambulances, because some of the equipment was no longer in a working condition (Du Toit \& Botes, 1996).

The results (P-value of 0,83773 ) indicate that there is a positive correlation between the causes of stress originating within the work situation and career matters, which implies that firefighters feel that they lack sufficient opportunities for career promotion and development. Confirming literature findings were experienced. Career matters are characterised by limited career and promotion opportunities, insufficient training, and failure to optimally utilise the abilities and potential of firefighters. This concern about career development impacts on their stress and motivation levels (Beaton et al., 2001).

The results (P-value of 0,75479 ) indicate that there is a positive correlation between the causes of stress originating within the work situation and social matters, which implies that relationships between firefighters and their colleagues, supervisors and management are stressful. Similar literature findings were found. Prolonged periods spent in the company of the same group of colleagues may cause irritability with each other (Seedat, La Grange, Niehaus \& Stein, 2003). Firefighters therefore need to make sure that they interact and link with people outside the work context and build on effective support structures. Effective interpersonal and conflict resolution skills also seem of prime importance (Pike, 2003).

The results (P-value of 0,76041 ) indicate that there is a positive correlation between the causes of stress originating within the work situation and remuneration, fringe benefits and personnel policy, which implies that firefighters feel that their salaries are poor and their fringe benefits are inadequate, and that different personnel policies are applicable in different areas of the metropolitan municipality. Confirming literature findings were found. Most firefighter's identities are associated with the type of work they do and if a firefighter's work is considered by significant other as inferior, it effects the firefighter's self-image (Pike, 2003). Differences exist with regard to salary structures, fringe benefits and personnel policy (Fontana, 1994).

The results (P-value of 0.74186 ) indicate that there is a positive correlation between career matters and organisational functioning, which implies that firefighters consider their upward 
mobility and development in their careers in relation to their functions in the emergency services (fire service). Similar literature findings were found. Insufficient training can lead to unnecessary mistakes and incorrect decisions (Beaton et al., 2001).

A further analysis of the results confirmed the third hypothesis that there are certain correlations between the subscales of the Stress questionnaire (inter alia: somatication, obsessive-compulsive behaviour, interpersonal sensitivity, depression and anxiety). Correlation statistics in Table 9 provides the following significant Pearson Correlation Coefficients of the Stress questionnaire.

TABLE 9

Pearson Correlation coefficients of the stress QUESTIONNAIRE

\begin{tabular}{lllllll}
\hline & $\begin{array}{c}\text { Mean } \\
\text { SQ 1 }\end{array}$ & $\begin{array}{c}\text { Mean } \\
\text { SQ 2 }\end{array}$ & $\begin{array}{c}\text { Mean } \\
\text { SQ 3 }\end{array}$ & $\begin{array}{c}\text { Mean } \\
\text { SQ 4 }\end{array}$ & $\begin{array}{c}\text { Mean } \\
\text { SQ 5 }\end{array}$ & $\begin{array}{c}\text { Stress } \\
\text { total 2 }\end{array}$ \\
\hline Mean SQ 1 & 1,00000 & $\begin{array}{l}0,68141 \\
<, 0001\end{array}$ & $\begin{array}{l}0,60989 \\
<, 0001\end{array}$ & $\begin{array}{l}0,65946 \\
<, 0001\end{array}$ & $\begin{array}{l}0,65309 \\
<, 0001\end{array}$ & $\begin{array}{l}0,26091 \\
<, 0001\end{array}$ \\
Mean SQ 2 & 0,68141 & 1,00000 & 0,62440 & 0,70281 & 0,64423 & 0,30902 \\
& $<, 0001$ & & $<, 0001$ & $<, 0001$ & $<, 0001$ & $<, 0001$ \\
Mean SQ 3 & 0,60989 & 0,62440 & 1,00000 & 0,72989 & 0,65085 & 0,23957 \\
& $<, 0001$ & $<, 0001$ & & $<, 0001$ & $<, 0001$ & 0,0002 \\
Mean SQ 4 & 0,65946 & 0,70281 & 0,72989 & 1,00000 & 0,78442 & 0,32887 \\
& $<, 0001$ & $<, 0001$ & $<, 0001$ & & $<, 0001$ & $<, 0001$ \\
Mean SQ 5 & 0,65309 & 0,64423 & 0,65085 & 0,78442 & 1,00000 & 0,32793 \\
& $<, 0001$ & $<, 0001$ & $<, 0001$ & $<, 0001$ & & $<, 0001$ \\
Stress total 2 & 0,26091 & 0,30902 & 0,23957 & 0,32887 & 0,32793 & 1,00000 \\
& $<, 0001$ & $<, 0001$ & 0,0002 & $<, 0001$ & $<, 0001$ & \\
\hline
\end{tabular}

Note

Mean SQ 1 = Mean of somatic component of Stress questionnaire

Mean SQ 2 = Mean of obsessive-compulsive component of Stress questionnaire

Mean SQ $3=$ Mean of interpersonal sensitivity component of Stress questionnaire

Mean SQ $4=$ = Mean of depression component of Stress questionnate

Mean SQ $5=$ Mean of anxiety component of Stress questionnairestres

total 2 = Stress total for the Stress questionnaire
The results (P-value of 0,70281 ) indicate that there is a significant correlation between depression and obsessive-compulsive behaviour, which implies that firefighters that experience depression tend to behave in an obsessive-compulsive manner. Similar literature findings were found. Obsessions can be potent and persistent enough to interfere with daily life and can engender significant depression (Nevid, Rathus \& Greene, 2005).

The results (P-value of 0,72989) indicate that there is a significant correlation between depression and interpersonal sensitivity, which implies that firefighters that experience depression tend to be very sensitive regarding personal matters. Confirming literature findings were found. Dependent firefighters are focused on interpersonal issues, they need others' approval to maintain a sense of well-being. Depression is triggered in dependent firefighters when they perceive disruptions in their relationships with others, interpersonal loss, abandonment, or social rejection (O’Neill, Cohen, Tolpin \& Gunthert, 2004).

The results (P-value of 0,78442 ) indicate that there is a significant correlation between anxiety and depression, which implies that firefighters that experience anxiety tend to be also depressed. Similar literature findings were found. Anxiety, which is very often the result of changes in brain chemistry, may take the form of psychomotor agitation, tremor, tenseness, irritability, and incapacity to experience a sense of comfort and peacefulness (Elliot, Goldberg, Duncan \& Kuehl, 2004). Firefighters in depression generate thoughts of a foreboding nature. Anticipation of the unknown also adds to the state of anxiety, compounding the symptoms of depression (Fishkin, 1992; Monnier, Cameron, Hobfoll \& Gribble, 2000).

The investigation into the relationship between job stressors (causes originating within the work situation) and family stressors (causes arising outside the work situation) produced the following results. Table 10 provides a comparison of the correlation matrix of the subscales of the Experience of work and life circumstances questionnaire and Stress questionnaire.

TABLE 10

PEARSON CORRELATION COEFFICIENTS OF THE EXPERIENCE OF WORK AND LIFE CIRCUMSTANCES QUESTIONNAIRE AND STRESS QUESTIONNAIRE

\begin{tabular}{|c|c|c|c|c|c|c|c|c|c|c|}
\hline & Level & COW & Field 1 & Field 2 & Field 3 & Field 4 & Field 5 & Field 6 & CIW & $\begin{array}{r}\text { Stress } \\
\text { total } 1\end{array}$ \\
\hline Mean SQ 1 & $\begin{array}{r}0,50714 \\
<, 0001\end{array}$ & $\begin{array}{r}0,41417 \\
<, 0001\end{array}$ & $\begin{array}{r}-0,23322 \\
0,0003\end{array}$ & $\begin{array}{r}-0,06125 \\
0,3530\end{array}$ & $\begin{array}{r}-0,17799 \\
0,0066\end{array}$ & $\begin{array}{r}-0,23640 \\
0,0003\end{array}$ & $\begin{array}{r}-0,29119 \\
<, 0001\end{array}$ & $\begin{array}{r}-0,24400 \\
0,0002\end{array}$ & $\begin{array}{r}-0,26091 \\
<, 0001\end{array}$ & $\begin{array}{r}0,21045 \\
0,0013\end{array}$ \\
\hline Mean SQ 2 & $\begin{array}{r}0,51417 \\
<, 0001\end{array}$ & $\begin{array}{r}0,43184 \\
<, 0001\end{array}$ & $\begin{array}{r}-0,17641 \\
0,0071\end{array}$ & $\begin{array}{r}-0,11779 \\
0,0734\end{array}$ & $\begin{array}{r}-0,13659 \\
0,0376\end{array}$ & $\begin{array}{r}-0,15685 \\
0,0168\end{array}$ & $\begin{array}{r}-0,29027 \\
<, 0001\end{array}$ & $\begin{array}{r}-0,17053 \\
0,0093\end{array}$ & $\begin{array}{r}-0,22074 \\
0,0007\end{array}$ & $\begin{array}{r}0,25888 \\
<, 0001\end{array}$ \\
\hline Mean SQ 3 & $\begin{array}{r}0,61257 \\
<, 0001\end{array}$ & $\begin{array}{r}0,45714 \\
<, 0001\end{array}$ & $\begin{array}{r}-0,36889 \\
<, 0001\end{array}$ & $\begin{array}{r}-0,13074 \\
0,0467\end{array}$ & $\begin{array}{r}-0,24416 \\
0,0002\end{array}$ & $\begin{array}{r}-0,32002 \\
<, 0001\end{array}$ & $\begin{array}{r}-0,45404 \\
<, 0001\end{array}$ & $\begin{array}{r}-0,25240 \\
0,0001\end{array}$ & $\begin{array}{r}-0,36872 \\
<, 0001\end{array}$ & $\begin{array}{r}0,18853 \\
0,0040\end{array}$ \\
\hline Mean SQ 4 & $\begin{array}{r}0,60787 \\
<, 0001\end{array}$ & $\begin{array}{r}0,50528 \\
<, 0001\end{array}$ & $\begin{array}{r}-0,25676 \\
<, 0001\end{array}$ & $\begin{array}{r}-0,12772 \\
0,0520\end{array}$ & $\begin{array}{r}-0,13924 \\
0,0340\end{array}$ & $\begin{array}{r}-0,27656 \\
<, 0001\end{array}$ & $\begin{array}{r}-0,38900 \\
<, 0001\end{array}$ & $\begin{array}{r}-0,20722 \\
0,0015\end{array}$ & $\begin{array}{r}-0,29109 \\
<, 0001\end{array}$ & $\begin{array}{r}0,27578 \\
<, 0001\end{array}$ \\
\hline Mean SQ 5 & $\begin{array}{r}0,52934 \\
<, 0001\end{array}$ & $\begin{array}{r}0,35769 \\
<, 0001\end{array}$ & $\begin{array}{r}-0,14439 \\
0,0279\end{array}$ & $\begin{array}{r}-0,05245 \\
0,4265\end{array}$ & $\begin{array}{r}-0,12437 \\
0,0586\end{array}$ & $\begin{array}{r}-0,17680 \\
0,0069\end{array}$ & $\begin{array}{r}-0,27672 \\
<, 0001\end{array}$ & $\begin{array}{r}-0,11794 \\
0,0730\end{array}$ & $\begin{array}{r}-0,18374 \\
0,0050\end{array}$ & $\begin{array}{r}0,27714 \\
<, 0001\end{array}$ \\
\hline Stress total 2 & $\begin{array}{r}0,53901 \\
<, 0001\end{array}$ & $\begin{array}{r}0,41876 \\
<, 0001\end{array}$ & $\begin{array}{r}0,46264 \\
<, 0001\end{array}$ & $\begin{array}{r}0,47133 \\
<, 0001\end{array}$ & $\begin{array}{r}0,37789 \\
<, 0001\end{array}$ & $\begin{array}{r}0,48751 \\
<, 0001\end{array}$ & $\begin{array}{r}0,27208 \\
<, 0001\end{array}$ & $\begin{array}{r}0,44384 \\
<, 0001\end{array}$ & $\begin{array}{r}0,55114 \\
<, 0001\end{array}$ & $\begin{array}{r}0,99804 \\
<, 0001\end{array}$ \\
\hline
\end{tabular}

Note

Level $=$ Stress level

COW $=$ Causes arising outside the work situation

Field $1=$ Organisational functioning

Field $2=$ Task characteristics

Field 3 = Physical working conditions and job equipment

Field 4 = Career matters

Field $5=$ Social matters

Field 6 = Remuneration, fringe benefits and personnel policy

$\mathrm{CIW}=$ Causes originating within the work situation

$\mathrm{CIW}=$ Causes originating within the work situation
Stress total $1=$ Stress total for the Experience of work and life circumstances questionnaire

Mean SQ 1 = Mean of somatic component of Stress questionnaire

Mean SQ 2 = Mean of obsessive-compulsive component of Stress questionnair

Mean SQ $3=$ Mean of interpersonal sensitivity component of Stress questionnaire

Mean SQ $4=$ Mean of depression component of Stress questionnaire

Mean SQ 5 = Mean of anxiety component of Stress questionnaire

Stress total $2=$ Stress total for the Stress questionnaire 
The correlations confirm that firefighters do experience job stress due to a number of causes originating within the work situation. The results indicate negative correlations between the causes arising outside the work situation and those originating within the work situation. This phenomenon can be explained by the fact that an increase in job stressors will not necessarily contribute to an increase in family stressors. The questionnaires measure stressors and not stress and the experience thereof. The possibility exists that a transfer effect may occur. An increase in job stress may influence the stress reactions rather than the stressors of the family. These two constructs namely job and family stressors were measured independently in this instrument.

\section{DISCUSSION}

Firefighters regard family stress as a major cause of stress arising outside the organisation, whereas they experience task characteristics as the main cause of stress originating within the work situation. Organisational functioning, physical working conditions and inadequate equipment caused the least stress within the work situation. Firefighters experienced career and social matters as well as remuneration, fringe benefits and personnel policy as moderate causes of stress originating within the work situation. A few firefighters had expressed thoughts about ending their lives (suicidal tendencies), but feelings of concern (depression) were generally indicated.

It was found that firefighters in the age category 26 - 30 years experience high family stress due to causes arising outside the work situation. The conclusion can be drawn that firefighters feel that their everyday financial obligations and the general economic situation in the country makes life exceptionally difficult for them. The phase of life in which they find themselves, for example, to be married and the birth of children, and the family crisis that are common during this phase, have an adverse effect on their lives. Firefighters in the age category 4154 years experience high job stress due to causes originating within the work situation, because they feel uncertain in their work. It is as if they are up against a wall and simply cannot make any progress. This may cause that they do not wish to participate in anything and have no real interest in their work activities.

The male firefighters experience higher levels of family stress due to causes arising outside the work situation than the female firefighters. They often feel in their everyday life that family stress caused by, for example, death, the responsibility to provide for the family, illness and strife, have an adverse effect on their lives. Furthermore, it was found that the male firefighters experience higher job stress due to causes originating within the work situation than female firefighters. The conclusion can be drawn that they often feel that no-one wants to support them in their work and that their particular work situation compares unfavourably with others. Married firefighters experience high levels of family stress due to causes arising outside the work situation. They have limited time to spent with their families because they are often away from their families for several days at a time, as they have to work shifts. Their absence may also cause that they experience problems with their children. Unmarried firefighters experience high job stress due to causes originating within the work situation. The conclusion can be drawn that they are often new in the fire service and inexperienced in their work with no support systems of marital partners and families to cope with traumatic incidents and sensory experiences.

Firefighters with 2 - 5 years' experience in their occupation experience high levels of family stress due to causes arising outside the work situation. The conclusion can be drawn that they often feel in their everyday life that rapidly changing technology poses a problem for them. Such feelings of insecurity about their abilities to cope with the new technology may be transferred to their families. They may feel that if they cannot cope, they may loose their jobs causing that they have no income to support their families. Firefighters with less than 2 years experience in their occupation experience high levels of job stress due to causes originating within the work situation. They often feel sad in their work and are often emotionally disturbed when involved in more tragic rescue operations.

Firefighters in the category Grade 10 - 11 experience high family stress due to causes arising outside the work situation. They feel that their abilities and skills are not developed and that they are not making progress in their careers. They have no expectations to provide a better life for their families. Firefighters in the category of Grade 10 - 11 experience high family stress due to causes originating within the work situation. The conclusion can be drawn that they often feel dissatisfied with their promotion due to lack of resources (Monnier et al., 2002).

The researchers found that family stressors manifested in terms of limited time spend with family. The effects of shift work as another cause of stress on marital functioning and the family was explored. The shifts worked by firefighters consist of three day shifts, three night shifts and three days off. If a marriage partner works, he or she may thus not see the firefighter for several days if their work schedules do not coincide (Shakespeare-Finch et al., 2002). Firefighters and law enforcement officers responds to shootings, car incidents and battered families, coupled with the immediate terror of an officer-involved shooting or a triple-fatality vehicle crash. The conclusion can be drawn that these type of situations may cause that they have to work longer hours resulting in limited time with their families.

There is evidence indicating, however, that family members particularly the marriage partners of firefighters - report a greater need for help than do firefighters. Some of the concerns reported by firefighters' marriage partners have focussed on shift work and the separations resulting from it, and reactions to the dangers posed by the firefighters' work. The conclusion can be drawn that the need for understanding and forbearance, combined with a lack of social structures to cope with reactions to the dangers of the firefighters' job, may contribute to marital dysfunction between marriage partners. Marriage partners often lack the social resources needed to mitigate the inherent family stresses of being married to a person in such a dangerous profession. There are many indicators that being married to a firefighter puts additional stress on a marriage and on family life (Shakespeare-Finch et al., 2002).

Furthermore, the researcher found that family stress manifested in terms of problems with children, the marriage partner being alone, firefighters not being available to help the family when needed, the effects of shift work and separation and financial problems. Firefighters reported that their children seemed much more aware of the danger in their parents' jobs than they had been previously (Elliot et al., 2004). Among both younger and older children, there was increased separation anxiety. The conclusion can be drawn that the three most common parental problems with children were anger and temper tantrums, clinginess, and separation fears.

Although the most frequent stress reported by the marriage partner related to the danger of the firefighters' jobs, the firefighters reported feeling anxious about their marriage partners and family being alone at night. The conclusion can be drawn that firefighters' marriage partners and families need to learn how to handle emergencies alone and how to tolerate long hours apart from the firefighter, as well as long hours together. Firefighters may also feel that previous traumatic incidents have prepared them to cope more effectively with a family crisis. Firefighters may aim at reducing the impact of a crisis on their family through their support, expression and 
normalisation of family reactions, as well as cognitive preparation of the family, for probable future experiences (Seedat et al, 2003). The conclusion can be drawn that the varied repertoire of personal resources found in firefighters is a result of learning through both formal prevention and intervention programmes, and the direct and indirect (i.e. modelling) effects of work experiences.

It was found that shift work had negative consequences for role performance in a marriage. Ongoing shift work seems to remove family members from the household at the times when their presence is most required. The conclusion can be drawn that little is known, however, about the effect of rotating shifts which is what most firefighters have - on marital success. It becomes apparent that longer shifts have a more negative influence on the family relationships of firefighters than shorter shifts. Firefighters also find it very difficult to provide in all the financial needs of their family. Firefighters are forced to work more shifts and longer hours to provide an additional income for their families. This also expose themselves to more trauma and dangers. They are also longer away from their families, with the subsequent negative impact on their marriage partners and children (Shakespeare-Finch et al., 2002).

\section{Recomemdations}

The following recommendations are made in terms of the research:

The first recommendation relates to the description and analysis of job stress amongst firefighters in the South African context by expanding the unique model of job stressors of firefighters through further research in this area. Specific areas of the model that can be expanded include the physical working conditions. It is recommended that the exposure to risks and danger, traumatic incidents and terrible sensory experiences be further investigated. Other areas of the model that can be expanded include the job equipment (new technology), limited career and promotion opportunities (insufficient training), and differences in salary structures and personnel policies.

The second recommendation relates to the description and analysis of family stress amongst firefighters in the South African context by expanding the existing literature of family stressors, family stress reactions and symptoms and results of family stress through further research in this domain. Specific areas of the existing literature can be expanded by investigating stress reactions and symptoms other than those dealt with in the research that are evident amongst family members of firefighters. It will also be worthwhile to conduct further research of the family stress interventions associated with these other stress reactions and symptoms.

\section{REFERENCES}

Beaton, R., Johnson, L.C., Infield, S., Ollis, T. \& Bond, G. (2001). Outcomes of a leadership intervention for a metropolitan fire department. Psychological Reports, 88 (3), 1049-1066.

Bless, C. \& Higson-Smith, C. (2000). Fundamentals of social research methods An African perspective. Lansdowne: Juta Education (Pty) Ltd.

Boss, P. (1988). Family stress management. California: SAGE Publications, Inc.

Burr, W.R. \& Klein, S.R. (1994). Re-examining family stress new theory and research. California: SAGE Publications, Inc.

Cox, T. (1978). Stress. Baltimore: University Park Press.

Cox, T. (2000). Research on work-related stress. Lanham, Md.: Bernan Associates.

Davison, G.C., Neale, J.M., Kring, A.M. (2004). Abnormal psychology. New York: John Wiley \& Sons.

Derogatis, L.R., Lipman, R.S., Rickles, K., Uhlenhuth, E.H. \& Covi, L. (1974). The Hopkins Symptom Checklist (HSCL): A self-report symptom inventory. Behavioural Science, 19, 1-15.
Dozois, D.J.A. \& Backs-Dermott, B.J. (2000). Sociotropic personality and information processing following imaginable priming: A test of the congruency hypothesis. Canadian Journal of Behavioural Science, 32 (2), 117-126

Du Toit, R.E. \& Botes, G. (1996). Stressors experienced and support received for managing stress in the emergency services in Cape Town, Durban and Pretoria (Report). Pretoria: HSRC.

Elliot, D.L., Goldberg, L., Duncan, T.E. \& Kuehl, K.S. (2004). The PHLAME Firefighters' Study: Feasibility and findings. American Journal of Health Behaviour, 28 (1), 13-23.

Fishkin, G.L. (1992). Treating alcoholism within the fire service. American Fire Journal, 18-20.

Fishkin, G.L. (1992). Firefighters and depression: Identification and treatment. American Fire Journal, 12.

Fontana, D. (1994). Problems in practice: managing stress. Great Britain: The British Psychological Society and Routledge.

Fullerton, S.C., Ursano, R.J. \& Wang, L. (2004). Acute stress disorder, posttraumatic stress disorder, and depression in disaster or rescue workers. The American Journal of Psychiatry, 161 (8), 1370-1376.

Garcia, E. (2003). Supporting the Federal Emergency Management Agency Rescuers: A variation of critical incident stress management. Military Medicine, 168 (2), 87-90.

Gmelch, W.H. (1982). Beyond stress to effective management. New York: Wiley.

Graham, N. (1981). Done in, fed up, burned out: Too much attrition in EMS. Journal of Emergency Medical Services, 6 (1), 24-29.

Hartsough, D. (1985). Perspectives on disaster recovery. In J. Laube. $\&$ S. Murphy (Eds.) Norwalk, CT: Applton-Century-Crofts.

He, N., Zhao, J. \& Archbold, C.A. (2002). Gender and police stress: The convergent and divergent impact of work environment, work-family conflict, and stress coping mechanisms of female and male police officers. Policing, 25 (4), 687-709.

Koortzen, P. (1996). Die dimensionaliteit van polisie-stressore. ACTA Criminologica Southern African Journal of Criminology, 9 (2), 55-63.

Lemanski, C. (2003). Psychological first aid: After debriefing. Fire Engineering, 156 (6), 73-75.

Linienfeld, S.O. (1998). Looking into abnormal psychology: Contemporary readings. Pacific Grove: Brooks/Cole Pub. Co.

Mitchell, J.T. (1983). When disaster strikes: The critical incident stress debriefing. Journal of Emergency Medical Services, 8 (1), 36-39.

Mitchell, J.T. \& Bray, G.P. (1990). Emergency Services Stress: Guidelines for preserving the health and careers of emergency services personnel. Englewood Cliffs, N.J: Prentice-Hall.

Monnier, J., Cameron, R.P., Hobfoll, S.E. \& Gribble, J.R. (2000). Direct and crossover effects of prosocial and antisocial coping behaviours. Journal of Family Psychology, 14 (4), 570584.

Monnier, J., Cameron, R.P., Hobfoll, S.E. \& Gribble, J.R. (2002). The impact of resource loss and critical incidents on psychological functioning in fire-emergency workers: A pilot study. International Journal of Stress Management, 9 (1), 11-29.

Nevid, J.S., Rathus, S.A. \& Greene, B. (2005). Abnormal psychology in a changing world media and research update, 5e. Upper Sadle River, NJ: Prentice-Hall.

O’Neill,S.C., Cohen, L.H., Tolpin, L.H., Gunthert, K.C. (2004). Affective reactivity to daily interpersonal stressors as a proactive predictor of depressive symptoms. Journal of Social and Clinical Psychology, 23 (2), 172-195.

Peltzer, K. (2001). Stress and traumatic symptoms among police officers at a South African police station. Acta Criminologica, 14 (3), 52-56.

Perry, M. (1999). Spousal support. Sheriff, 51 (3), 24-25

Phebe, T., Pfefferbaum, B., Noxon, J.S. \& Dickson, W. (2000). Predictors of posttraumatic stress syndrome in Oklahoma City: Exposure, social support, peri-traumatic responses. The Journal of Behavioural Health Sciences \& Research, 27 (4), 406416. 
Pike, A. (2003). Dealing with stress: Health and safety. Emergency Services $S A, 24$ (5), 20-21.

Regehr, C., Johanis, D., Dimitropoulos, G., Bartram, C. \& Hope, G. (2003). The police officer and the public inquiry: A Qualitative Inquiry into the aftermath of workplace trauma. Brief Treatment and Crisis Intervention, 3 (4), 383.

Roberts, N.A. \& Levenson, R.W. (2001). The remains of the workday: Impact of job stress and exhaustion on marital interaction in police couples. Journal of Marriage and the Family, 63 (4), 1052-1067.

SAS INSTITUTE. (1999). SAS user's guide: basics version. $8^{\text {th }}$ ed. Cary, NC: SAS Institute.

Seedat, S., La Grange, H., Niehaus, D. \& Stein, D.J. (2003). Stress and resilience in South African firefighters. South African Medical Journal, 93 (4), 236-238.

Shakespeare-Finch, J., Smith, S. \& Obst, P. (2002). Trauma, coping resources, and family functioning in emergency services personnel: A comparative study. Work \& Stress, 16 (3), 275-282.

Smith, D.L., Manning, T.S. \& Petruzzello, S.J. (2001). Effect of strenuous drills on cardiovascular and psychological responses of recruit firefighters. Ergonomics, 44 (3), 244-254.
Torres, S., Maggard, D.L. \& Torres, C. (2003). Preparing families for the hazards of police work. The Police Chief, 70 (10), 108

Van Zyl, \& Van der Walt, (1991). Manual for the Experience of Work and Life Circumstances Questionnaire. Pretoria: HSRC.

Waters, J.A. (2002). Moving forward from September 11: A stress/crisis/trauma response. Brief Treatment and Crisis Intervention, 2 (1), 55.

Wiese, L., Rothmann, S. \& Storm, K. (2003). Coping, stress and burnout in the South African Police service in KwaZulu Natal. South African Journal of Industrial Psychology, 29 (4), 71-80.

Willis, R.O. (1993). An examination of critical incident stress debriefing for emergency service providers: A quasi-experimental field survey. Unpublished Ph.D dissertation. Baltimore: University of Maryland.

Young, S.A. (2001). Posttraumatic stress disorder: Acute and long-term responses to trauma and disaster. The American Journal of Psychiatry, 158 (7), 1178. 